\title{
Adolescent Movement Cares About Menstrual Hygiene Management (MHM)
}

\author{
Fayakun Nur Rohmaha), and Siti Arifah \\ Fakultas IImu Kesehatan, Universitas 'Aisyiyah Yogyakarta, Yogyakarta, Indonesia \\ a)Corresponding author : fayakun.nurrohmah@unisayogya.ac.id
}

\begin{abstract}
Lack of knowledge about The Menstrual Hygiene Management (MHM) and poor water sanitation is a problem in adolescents in Indonesia. This community service activity aims to increase students' knowledge and awareness about MHM. This community service was carried out in October 2019 at SD Muhammadiyah Karangkajen I and SD Muhammadiyah Karangkajen II followed by 25 students from grades IV, $\mathrm{V}$ and $\mathrm{V}$. The design of this activity is the provision of training on MKM by providing training modules and applying several learning methods including lectures, discussions, and simulations that begin with pretest and end postest. The results showed there was a difference in the average value of knowledge of students to MKM and statistically significant $p<0.05$. It is expected that students can do MHM appropriately and provide the right information to friends. Teachers are expected to play an active role in providing information about reproductive health so that students get accurate information
\end{abstract}

Kata kunci : Menstrual Hygiene Management (MHM), adolescents

\section{INTRODUCTION}

Lack of knowledge about Menstrual Hygiene Management (MHM) and poor water sanitation is a problem in adolescents in Indonesia (Kemenkes RI, 2017). UNESCO studies in various cultures show menstruation is considered a taboo thing to talk about because it is considered a negative, and embarrassing thing. Even about $20 \%$ of girls in urban and rural areas believe menstruation is a disease (Hastuti et al., 2019).

One of the impacts on education when teenagers menstruate is the absence from school. Some of the reasons that cause not entering school, including menstrual pain and no pain medication available at school, improper bathroom conditions, availability of clean water, availability of pads, unavailability of trash cans and wrappers to dispose of used pads. In addition, the actions of male students who sometimes mock also make students reluctant to go to school. (Kementrian Pendidikan dan Kebudayaan, 2017).

Cleanliness of the genitalia during menstruation such as changing pads and cleaning around the vagina prevents the occurrence of urinary tract infections (UTIs), reproductive tract infections (ISR), and irritation of the skin. Risk factors for these problems include poor habits such as low handwashing behavior before and after changing pads, rarely replacing pads, and myths and values that prohibit women from shampooing, bathing, and cutting nails during menstruation.(Kementrian Pendidikan dan Kebudayaan, 2017).

Most young women do not have enough knowledge about hygiene during menstruation. Most young women do not understand about before washing their genitals should wash their hands with soap first, knowledge of how to wash the correct vagina, knowledge about wearing panties, and knowledge about the use of pantyliners. Studies show about $50 \%$ of girls have poor knowledge of hygiene during menstruation. Knowledge of reproductive health issues will have an impact on individual attitudes and behaviors in a person's life. (Pythagoras, 2017).

The practice of maintaining cleanliness during menstruation in young women in Indonesia needs to be a concern because most young women, in the beginning, get menstruation. The frequency of dressing changes varies 2-6 times per day according to the amount of blood that comes out. The majority of schoolgirls change pads 3 times a day, which means that it is not following the recommendation that pads should be replaced every 3-4 hours. The tendency of young women not to change their pads at school for reasons of comfort in 
facilities such as the availability of separate toilets between men and women, adequate water availability, trash cans for used pads, and fear of being caught by male students. Students rarely or only ever change pads at school when their menstrual blood is full or has been translucent. The habit of washing hands before and after changing pads has also not become a habit in young women. Only about $40 \%$ of young women wash their hands using soap and running water (Hastuti et al., 2019). Based on this background, it is important to implement programs to increase students' knowledge and awareness about MHM.

\section{METHOD}

This community service was carried out in October 2019 at SD Muhammadiyah Karangkajen I and SD Muhammadiyah Karangkajen II. This activity was attended by 25 students from grades IV, V, and V. Participants who participated in this activity were representatives of each randomly selected class. The design of this activity is the provision of training on MKM by providing training modules and applying several learning methods including lectures, discussions, and simulations. Training materials consist of Understanding and physiology of menstruation, Actions when getting the first menstruation, where students can get pads, how to use and dispose of disposable pads, time to change pads, maintain hand hygiene, how to overcome complaints during menstruation, how to take a mandatory bath after finishing menstruation. Before the activity begins is preceded by the provision of a pretest and ends with the postest to see the increase in the knowledge of students. Analysis of pretest and posttest data using the Paired Sample T-Test.

\section{RESULTS}

The characteristics of the trainees have mostly been menstruating by $95 \%$. The results of the data analysis found differences in average knowledge scores before and after MKM training in students was carried out. There was an increase in the score on the postest to 10.4 from the pretest average of 6.4. Statistical test results using the Paired Sample T-Test show $p<0.05$, Then it can be concluded that there is a difference in knowledge about MHM before being given training and after getting training in students.

\section{DISCUSSION}

One of the internal factors that affect the behavior of young women in the management of menstrual hygiene is knowledge. Some studies show that the majority of young women already have a good knowledge of hygiene behavior during menstruation.(Nurmayani et al., 2020)(Husni, 2018)(Mustikawati, 2013). However, some things still need to be improved such as the frequency of dressing and paying attention to hand hygiene when going to and after changing pads. Prolonged use of pads can lead to an increased risk of infection of the urinary tract, and bacterial vaginosis.(UNICEF, 2019). Poor management of menstrual hygiene can increase the risk of 1.3 times experiencing vaginal discharge (Anand et al., 2015) (Yanti, 2017). The same is revealed by other sources that related to the practice of washing hands when replacing pads, only some students wash their hands before changing pads and most do not use soap (Hastuti et al., 2019). Ignoring hand hygiene can have an impact on reproductive health. (Yanti, 2017).

Another thing that is an external factor that can affect the behavior of maintaining the cleanliness of the genitalia during menstruation is a source of information. Research at a top school showed that the majority of schoolgirls get information about the hygiene of the genitalia during menstruation from teachers $(17.9 \%)$, the internet $(47 \%)$, parents $(13.6 \%)$, textbooks $(12.7 \%)$, health workers $(12.5 \%)$, friends $(10.2 \%$,$) and the media (9.6 \%)$ (Setyorini \& Lieskusumastuti, 2020). Understanding the cleanliness of menstruation will affect the attitude and behavior of students, so the accuracy of information becomes important. The availability of information earlier and from a variety of reliable sources can affect adolescents' behavior towards menstrual hygiene better (Maharani \& Andryani, 2018). Information about inadequate reproductive health will have an impact on ongoing problems and affect the status of adolescent 
reproductive health (Octaviani \& Rokhanawati, 2020). In this case, the role of the Teacher is needed in the school so that the Teacher must also be equipped with a good knowledge of mentruation and MHM (Kaur et al., 2018).

Counseling provided by health workers is expected to provide the right information to students. Information is one of the factors that influence a person directly or indirectly. The ease of obtaining information, the frequency of receiving, and exposure to information from the surrounding environment enriches the knowledge gained (Pythagoras, 2017). The purpose of counseling is an effort to convey health messages / information to the public, groups or individuals that are expected to bring consequences to changes in knowledge and underlying one's behavior (Peiliana, 2019).

\section{CONCLUSIONS AND RECOMMENDATIONS}

There was an average increase in the knowledge score about MHM in students during the posttest. It is expected that the average increase it's can improve the behavior of MHM and participants can convey to other students about the correct MHM information. In addition, the Teacher is expected to play an active role in providing information about reproductive health, so that students get accurate information.

\section{ACKNOWLEDGMENTS}

Thank you to the University of 'Aisyiyah Yogyakarta through the Institute of Research and Community Service (LPPM) for the funding provided for this activity. Thank you to the Principal of Karangkajen I Elementary School and Karangkajen II Elementary School who has partnered with the team, giving permission and assistance so that activities can be carried out properly..

\section{REFERENCES}

Anand, E., Singh, J., \& Unisa, S. (2015). Menstrual hygiene practices and its association with reproductive tract infections and abnormal vaginal discharge in India. Sexual \& Reproductive Healthcare, 1-6. https://doi.org/10.1016/j.srhc.2015.06.001

Hastuti, Dewi, R. K., \& Pramana, R. P. (2019). Studi Kasus tentang Manajemen Kebersihan Menstruasi ( MKM ) Siswa SD dan SMP di Indonesia.

Husni, H. (2018). Hubungan Pengetahuan Dan Sikap Dengan Tindakan Personal Hygiene Saatmenstruasi Pada Remaja Putri. Jurnal Media Kesehatan, 9(2), 165-170. https://doi.org/10.33088/jmk.v9i2.309

Kaur, R., Kaur, K., \& Kaur, R. (2018). Menstrual Hygiene, Management, and Waste Disposal: Practices and Challenges Faced by Girls/Women of Developing Countries. Journal of Environmental and Public Health, 2018. https://doi.org/10.1155/2018/1730964

Kemenkes RI. (2017). Manajemen Kebersihan Menstruasi Perlu Dipahami. Indonesia. http://sehatnegeriku.kemkes.go.id

Kementrian Pendidikan dan Kebudayaan. (2017). Panduan Manajemen Kebersihan Menstruasi Bagi Guru dan Orang Tua. In Who/Unicef. https://www.unicef.org/indonesia/sites/unicef.org.indonesia/files/2019-05/MHM Guidance for Teacher and Parents-PMRC-Recommendation.pdf

Maharani, R., \& Andryani, W. (2018). Faktor Yang Berhubungan dengan Perilaku Personal Hygiene Saat Menstruasi pada Santriwati di MTs Pondok Pesantren Dar El Hikmah Kota Pekanbaru. KESMARS: Jurnal Kesehatan Masyarakat, Manajemen Dan Administrasi Rumah Sakit, 1(1), 69-77. https://doi.org/10.31539/kesmars.v1i1.172

Mustikawati, I. S. (2013). Perilaku Personal Hygiene Pada Pemulung Di TPA Kedaung Wetan Tangerang. Forum IImiah, 10(1), 27-35.

Nurmayani, W., Mulianingsih, M., Hadi, I., \& Suitari, R. A. (2020). Perilaku Remaja Putri Tentang Personal Hygiene Saat Menstruasi Pasca Gempa Di Dusun Lendang Bila Desa Tegal Maja Kecamatan Tanjung Kabupaten Lombok Utara. Jurnal IImu Keperawatan Maternitas, 3(2), 
1-9. https://doi.org/10.32584/jikm.v3i2.517

Octaviani, M., \& Rokhanawati, D. (2020). Association information sources of reproductive health with sexual behavior of adolescents in Indonesia. International Journal of Health Science and Technology, 1(3), 68-74.

Pemiliana, P. D. (2019). Perilaku Remaja Putri Dengan Personal Hygiene Saat Menstruasi Di Sma Etidlandia Medan Tahun 2018. Gaster, $17(1), \quad 62$. https://doi.org/10.30787/gaster.v17i1.341

Pythagoras, K. C. (2017). FEMALE ADOLESCENTS PERSONAL HYGIENE DURING MENSTRUATION. Jurnal Promkes, 5(1), 12-24. https://doi.org/10.1007/978-3-319-937014_44

Setyorini, C., \& Lieskusumastuti, A. D. (2020). Pengetahuan Siswi Tentang Kebersihan Organ Genetalia Eksterna Di Smkn 1 Banyudono Boyolali. Journal of Health Research, 3(2), 114122. http://www.elsevier.com/locate/scp

UNICEF. (2019). Guidance on Menstrual Health and Hygiene. www.unicef.org/wash\%0Ahttps://www.unicef.org/wash/files/UNICEF-Guidance-menstrualhealth-hygiene-2019.pdf

Yanti, D. E. (2017). Faktor Risiko Yang Berhubungan Dengan Kejadian Flour Albus Pada Remaja Putri Di Pondok Pesantren Darul A'mal Kota Metro. Jurnal Dunia Kesmas Volume, 6(3), $121-129$. 


\section{APPENDIX}

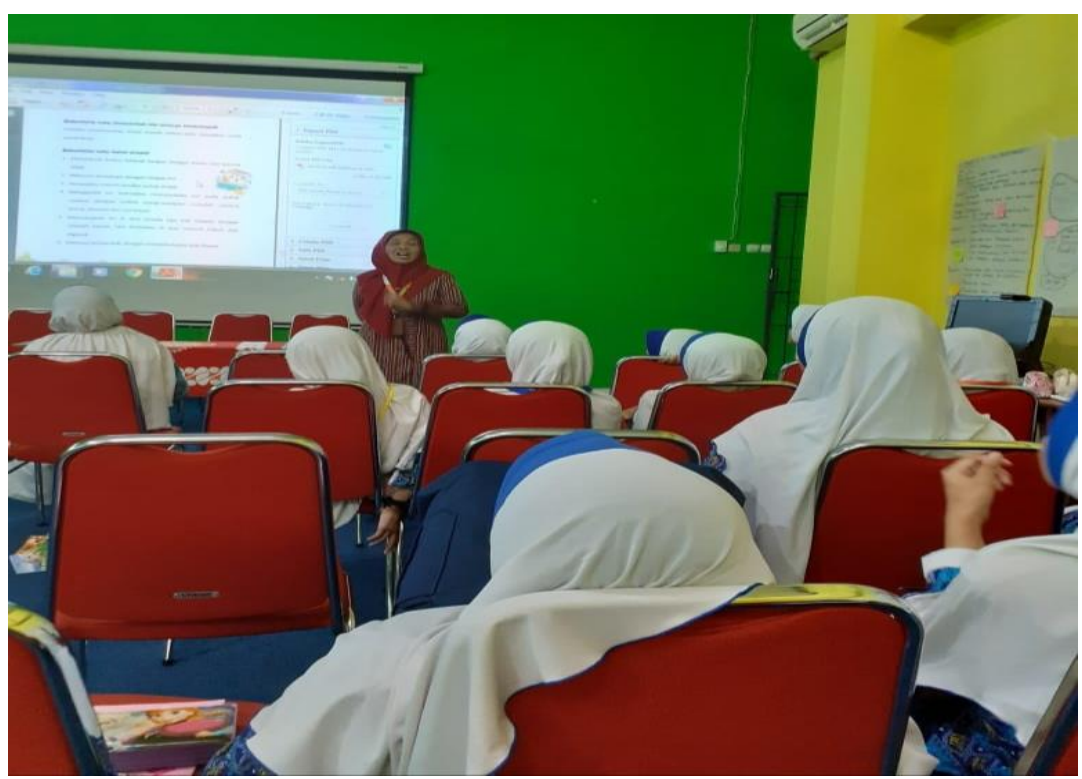

Figure 1. Students cadre training

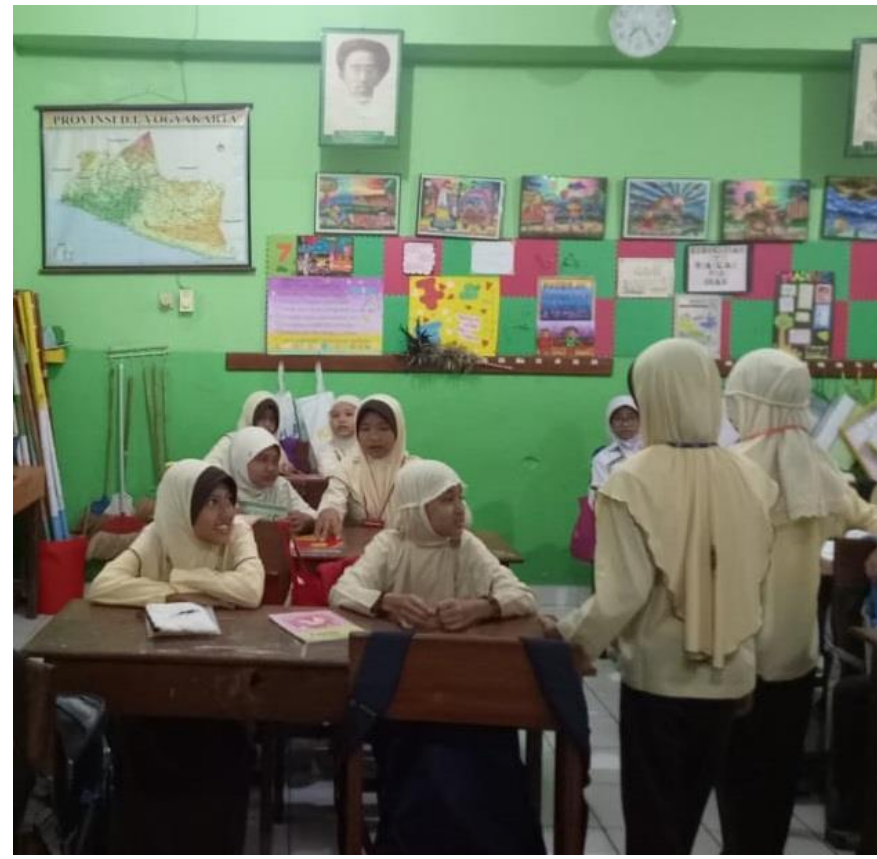

Figure 2. Simulation of giving materials by students cadre 